\title{
CXADR Gene
}

National Cancer Institute

\section{Source}

National Cancer Institute. CXADR Gene. NCI Thesaurus. Code C104699.

This gene is involved in both cell-cell adhesion and viral infection. 